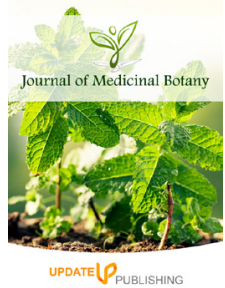

ISSN: $2521-3903$
Received: April 19, 2020 Accepted: May 03, 2020 Published: May 06, 2020

*Corresponding Author: Vijender Kumar

Email: vijenderpareek24@ yahoo.com

\section{In-vitro antiulcer activities of petal extract of Crocus sativus var. cashmerianus}

\author{
Vijender Kumar ${ }^{1 *}$ Poonam Verma², Amarjit Kaur³, Baljinder Singh ${ }^{2}$ \\ 'University Institute of Pharmaceutical Sciences \& Research, BFUHS, Faridkot-151203, Punjab, India, ²ala Lajpat Rai

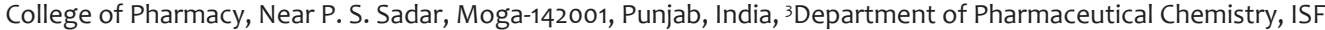 \\ College of Pharmacy, Moga-142001, Punjab, India
}

\begin{abstract}
Medicinal plants have been known for millennia as a rich source of traditional therapeutic agents for the prevention of diseases and ailments. The aim of the present study was performed to evaluate the antiulcer activities of hydroalcoholic extracts of petals of Crocus sativus var. Cashmerianus by in-vitro methods viz. acid neutralizing capacity and $\mathrm{H}^{+} / \mathrm{K}^{+}$- ATPase inhibition activity. In acid neutralizing capacity method, the petals extract significantly reduced acidity to 6.10 at a concentration of $1000 \mathrm{mg} / \mathrm{ml}$ as compared to 11.90 with standard $500 \mathrm{mg} / \mathrm{ml}$ of Aluminium hydroxide + Magnesium hydroxide combination. However, $\mathrm{H}^{+} / \mathrm{K}^{+}$- ATPase inhibition activity method, petals extract showed maximum percentage inhibition of $70.31 \%$ at the concentration $400 \mu \mathrm{g} / \mathrm{ml}$ as compared to $73.82 \%$ with a similar dose of standard Omeprazole. The IC 50 value of petals extract of C. sativus var. cashmerianus is shown $100 \mu \mathrm{g} / \mathrm{ml}$ in comparison with standard omeprazole of $82.5 \mu \mathrm{g} / \mathrm{ml}$. The study reveals that the petals extract of C. sativus var. cashmerianus may contain compounds possessing acid neutralize and enzyme inhibition activities, thus it can be used as an alternative medicine for gastrointestinal disorders.
\end{abstract}

KEYWORDS: C. sativus, Acid Neutralizing capacity, $\mathrm{H}^{+} / \mathrm{K}^{+}$- ATPase inhibition activity, Omeprazole

\section{INTRODUCTION}

Peptic ulcer is formed by an imbalance between gastro duodenal mucosal defence mechanisms and the aggressive factors, particularly gastric acid and pepsin. Ulceration is reported for high chances of recurrence and mortality [1]. Gastric acid is an important factor for the genesis of ulceration in stomach. The activation of the vagus-vagal refluxes by stimulation of pressure receptors in the antral gastric mucosa is believed to increase gastric acid secretion [2]. Phytoconstituents like flavonoids i.e. quercetin, catechin seems to play a very important role in promoting mucus secretion for prevention and treatment of peptic ulcer [3]. In addition to this, quercetin has reported to inhibit the growth of $H$. pylori bacterium in-vitro studies. Catechin interferes with the formation of histamine in gastric mucosa and hence produces the protective effect [4]. Presently, a dire need of most effective and safer anti-ulcer agents aiming to relieve pain, heal the ulcer and delay ulcer recurrence. Therefore herbal medicines are considered safer alternatives because of natural ingredients with no side effects. Petals extracts of Crocus sativus has reported for their antioxidants, anti-inflammatory and antibacterial activities. The present study to evaluate antiulcer activity of hydro-alcoholic extract of petals of Crocus sativus var. Cashmerianus by in-vitro methods viz. acid neutralizing capacity and $\mathrm{H}^{+} / \mathrm{K}^{+}$- ATPase inhibition activity. Therefore, an attempt had been made to validate its traditional claim as anti ulcer agent by these selected methods.

\section{MATERIAL AND METHODS}

\section{Plant Material}

The petals of Crocus sativus "Cashmerianus" were collected from Pampore area of Kashmir (J\&K, India). The petals were collected, shade dried and powdered in coarse form. Hydroalcoholic extract of petals was prepared, dried and used for further research work.

\section{In-vitro Evaluation of Antiulcer Activity}

Acid neutralizing capacity

The acid neutralizing capacity (ANC) value for hydro-alcoholic extract of petals of C. sativus "cashmerianus in different concentrations $(100 \mathrm{mg} / \mathrm{ml}, 200 \mathrm{mg} / \mathrm{ml}, 500 \mathrm{mg} / \mathrm{ml}, 1000 \mathrm{mg} / \mathrm{ml}$ ) 
were compared with the standard antacid AHMH (aluminum hydroxide + magnesium hydroxide $-500 \mathrm{mg} / \mathrm{ml}$ ). To the $5 \mathrm{ml}$ quantity of each extract individually, water was added and mixed well to make up the total volume up to $70 \mathrm{ml}$. Then $30 \mathrm{ml}$ of $1 \mathrm{~N} \mathrm{HCl}$ was added into standard and test preparation and stirred for 15 minutes, 2-3 drops of phenolphthalein solution was added and mixed. The excess $\mathrm{HCl}$ was immediately titrated with $0.5 \mathrm{~N}$ Sodium hydroxide solution drop wise until a pink color is appeared [5].

The moles of acid neutralized is calculated by,

Moles of acid neutralized $=($ vol. of $\mathrm{HCl} \times$ Normality of $\mathrm{HCl})$ - (vol. Of $\mathrm{NaOH} \times$ Normality of $\mathrm{NaOH})$

Acidneutralizingcapacity (ANC)

per gram of antacid $=\frac{\text { Moles of HClneutralized }}{\text { Grams of Antacid } / \text { Extract }}$

\section{Determination of $\mathrm{H}^{+} \mathrm{K}^{+}$ATPase inhibition}

\section{Preparation of $\mathrm{H}^{+/} \mathrm{K}^{+}$- ATPase enzyme}

Preparation of $\mathrm{H}^{+/} \mathrm{K}^{+}$- ATPase Enzyme: To prepare $\mathrm{H}^{+/}$ $\mathrm{K}^{+}$- ATPase enzyme sample, fresh sheep stomach was obtained from a local slaughterhouse of Moga city market. The sheep stomach was cut opened, washed, entire mucosa at gastric fundus was cut-off, and the inner layer was scraped out for parietal cells. Then parietal cells were homogenized in $16 \mathrm{mM}$ Tris buffer (pH 7.4) containing 10\% Triton X-100 and centrifuged at 5000xg for $10 \mathrm{~min}$. The supernatant (enzyme extract) was separated and used to determine the $\mathrm{H}^{+} / \mathrm{K}^{+}$- ATPase inhibition activity. The protein concentration in the supernatant was determined with bovine serum albumin used as standardreagent. The parietal cell extract was then used to determine $\mathrm{H}^{+} \mathrm{K}^{+}$ATPase activity.

\section{Assessment of $\mathrm{H}^{+/} \mathrm{K}^{+}$ATPase inhibition}

The reaction mixture containing $0.1 \mathrm{ml}$ of $\mathrm{H}^{+/} \mathrm{K}^{+}$- ATPase Enzyme $(300 \mu \mathrm{g} / \mathrm{ml})$ and petals extract at different concentrations $(25 \mu \mathrm{g}, 50 \mu \mathrm{g}, 100 \mu \mathrm{g}, 200 \mu \mathrm{g}, 400 \mu \mathrm{g})$ was pre-incubated for $60 \mathrm{~min}$ at $37^{\circ} \mathrm{C}$. The reaction was initiated by adding substrate $2 \mathrm{mM}$ Adenosine triphosphate $(200 \mu \mathrm{L})$, in addition to this $2 \mathrm{mM}$ $\left.\mathrm{MgCl}_{2} 200 \mu \mathrm{L}\right)$ and $10 \mathrm{mM} \mathrm{KCl}(200 \mu \mathrm{L})$ was added. After $30 \mathrm{~min}$ of incubation at $37^{\circ} \mathrm{C}$, the reaction was stopped by the addition of assay mixture containing $4.5 \%$ ammonium molybdate and $60 \%$ perchloric acid followed by centrifugation at $2000 \mathrm{xg}$ for $10 \mathrm{~min}$ and inorganic phosphate released was measured UV spectrophotometer at $660 \mathrm{~nm}$. Further, inorganic phosphate was determined by Fiske-Subbarow method [4,6]. The enzyme source was also treated similarly with the standard drug omeprazole and the enzyme activity was measured.

The percent enzyme inhibition was calculated using the formula:

Percentage of inhibition $=\quad[$ Activity $($ control $)-$ Activity (test)/Activity (control) $] \times 100$

\section{RESULT AND DISCUSSION}

\section{In-vitro Acid Neutralizing Capacity}

The in-vitro acid neutralizing effects of hydro-alcoholic extract of petals of $C$. sativus "cashmerianus in different concentrations (100 mg, 200mg, 500mg, and $1000 \mathrm{mg}$ per ml) were compared with the standard antacid АНМН- $500 \mathrm{mg} / \mathrm{ml}$. The results showed concentration dependent reduction in acid neutralizing capacity per gm of antacid was found as 115.7, 42.17, 10.22 and 6.10 respectively. As Similar fashion, AHMH (500 mg) which is found ANC value 11.90 quite similar concentration of test drug. Whereas, test drug concentration $1000 \mathrm{mg}$ was found double to neutralize acid more significantly as compared to standard. The results are tabulated in Table 1 .

\section{In-vitro $\mathrm{H}^{+} / \mathrm{K}^{+}$- ATPase Inhibition Activity}

In-vitro $\mathrm{H}^{+} / \mathrm{K}^{+}$- ATPase inhibition activity of hydro-alcoholic extract of petals of Crocus sativus "cashmerianus" in different concentrations $(25 \mu \mathrm{g}, 50 \mu \mathrm{g}, 100 \mu \mathrm{g}, 200 \mu \mathrm{g}$ and $400 \mu \mathrm{g}$ per ml) were compared with the standard drug omeprazole in similar concentrations. The results of test and standard drugs shows concentration dependent inhibition in $\mathrm{H}^{+} / \mathrm{K}^{+}$- ATPase activity, concentration more than $100 \mu \mathrm{g}$ were found effective i.e., 47.52, 56.46 and $70.31 \%$ with test drug and 52.22, 62.47 and $73.82 \%$ inhibitions with $100 \mu \mathrm{g} / \mathrm{ml}, 200 \mu \mathrm{g} / \mathrm{ml}$ and $400 \mu \mathrm{g} / \mathrm{ml}$ of concentration respectively. The extract at concentration more than $400 \mu \mathrm{g} / \mathrm{ml}$ was found more than $70 \%$ inhibition in $\mathrm{H}^{+} / \mathrm{K}^{+}$- ATPase activity. The results are tabulated in Table 2 .

Table 1: Acid Neutralizing Capacity (ANC) of hydro-alcoholic extract of petals of Crocus sativus "cashmerianus" by invitro method.

\begin{tabular}{|c|c|c|c|}
\hline $\begin{array}{l}\text { Concentration } \\
(\mathrm{mg} / \mathrm{ml})\end{array}$ & $\begin{array}{l}\text { Volume of } \mathrm{NaOH} \\
\text { consumed }(\mathrm{ml})\end{array}$ & $\begin{array}{l}\mathrm{mEq} \text { of Acid } \\
\text { Consumed }\end{array}$ & $\begin{array}{c}\text { ANC per gram of } \\
\text { Antacid }\end{array}$ \\
\hline HECS*-100mg & 34.8 & 12.25 & 115.7 \\
\hline HECS*-200mg & 28.1 & 17.15 & 42.17 \\
\hline $\mathrm{HECS}^{*}-500 \mathrm{mg}$ & 43.2 & 9.68 & 10.22 \\
\hline HECS*- $1000 \mathrm{mg}$ & 37.6 & 12.1 & 6.10 \\
\hline AHMH*-500mg & 47.2 & 7.75 & 11.90 \\
\hline
\end{tabular}

*HECS- hydro-alcoholic extract of petals of Crocus sativus cashmerianus; $\mathrm{AHMH}$ - aluminium hydroxide + magnesium hydroxide

Table 2: In-vitro $\mathrm{H}^{+} / \mathrm{K}^{+}$- ATPase inhibition activity of hydroalcoholic extract of petals of Crocus sativus "cashmerianus".

\begin{tabular}{lcc}
\hline Concentration $(\mu \mathrm{g} / \mathrm{ml})$ & \multicolumn{2}{c}{ Percentage Inhibition (\%) $($ Mean \pm SEM) } \\
\cline { 2 - 3 } & Standard Omeprazole & HECS \\
\hline $25 \mu \mathrm{g}$ & $-42.55 \pm 2.83$ & $-20.21 \pm 1.93$ \\
$50 \mu \mathrm{g}$ & $-28.54 \pm 1.55$ & $-13.37 \pm 1.21$ \\
$100 \mu \mathrm{g}$ & $52.22 \pm 1.69$ & $47.52 \pm 1.42^{\mathrm{b}}$ \\
$200 \mu \mathrm{g}$ & $62.47 \pm 2.71^{\mathrm{a}}$ & $56.46 \pm 2.18^{\mathrm{a}}$ \\
$400 \mu \mathrm{g}$ & $73.82 \pm 2.52^{\mathrm{a}}$ & $70.31 \pm 1.43^{\mathrm{a}}$ \\
\hline
\end{tabular}

*HECS- hydro-alcoholic extract of petals of Crocus sativus cashmerianus; Values are expressed as mean \pm SD for six animals in each group. Statistically significant difference is expressed as ${ }^{\mathrm{a}} \mathrm{p}<0.01,{ }^{\mathrm{b}} \mathrm{P}<0.05$ 


\section{CONCLUSION}

The causes of peptic ulcer is unclear in most of the patients, generally accepted that it may results of imbalance between aggressive factors and the maintenance of mucosal integrity through the endogenous protection system [7]. Acidity is a common gastrointestinal problem due to excessive secretion of gastric acid or stomach acid inflames the stomach lining mucosa and produces ulceration [8]. Antacids act by neutralizing gastric acid and thereby reduce the gastric $\mathrm{pH}$ [9]. The acid neutralizing capacity of an antacid is the amount of per gm of acid that it can neutralize [5, 10]. In ANC, results showed concentration dependent reduction was found in acid neutralizing capacity vs. per gm of antacid used. Hyperchlorhydria is another gastric problem characterized by hypersecretion of hydrochloric acid from parietal cells of gastric mucosa through proton pump. $\mathrm{H}^{+}$/ $\mathrm{K}^{+}$- ATPase is a key enzyme of parietal cells that inducing acidity.In $\mathrm{H}^{+} / \mathrm{K}^{+}$-ATPase inhibition activity, the hydroalcoholic extract showed concentration dependent as similar like. It can be concluded that hydro-alcoholic extract of petals of Crocus sativus "cashmerianus" possess potent antiulcer activity.

\section{REFERENCES}

1. Kumar V.,Bhat Z.A., Kumar D., Khan N. A., Chashoo I.A., Ara I. Gastroprotective effect of leaf extracts of Basella alba var. alba against experimental gastric ulcers in rats.Braz. J. Pharmacogn., 2012, 22(3): 657-662.

2. Oates PJ, Hakkinen JP. Studies on the mechanism of ethanol-induced gastric damage in rats, Gastroenterology,1988 94: 10-21.

3. Middleton E, Kandaswami C, Theoharides TC. The effects of plant flavonoids on mammalian cells: implications for inflammation, heart disease, and cancer. Pharmacol Rev, 2000 52: 673-751.

4. Fatima S., Ramesh C., Qureshi A S. In-vitro evaluation of antiulcer activity of a polyherbal mixture. IOSR Journal of Pharmacy, 2018, 8:12: 55-59.

5. Garad MC, Upadhya MA, Kokare DM, Itankar PR. Aerial parts of Enicostemma littorale Blume serve as antipyretic and antacid: in vivo and in vitro evaluations. Pharmacognosy Communication 2012, 2(3):42-45

6. Gupta RKP, Pradeepa \& Hanumanthappa M. In vitro antioxidant and $\mathrm{H}^{+}, \mathrm{K}^{+}$- ATPase inhibition activities of Acalypha wilkesiana foliage extract. Journal of Pharmacy and BioAllied Sciences, 2013,5(3):214-223

7. Prasad K, et.al. Evaluation of antiulcer and in-vitro antioxidant activity of methanolic extract of Psidium guajava root in albino wistar rats. International Journal of Phytopharmacology, 2014,5(1):59-67.

8. Houshia OJ et al. Assessment of the value of the antacid contents of selected Palestinian plants.American Journal of Chemistry, 2012, 2(6):322-325.

9. MI Thabrew and LDAM Arawwawala. An overview of In vivo and In vitro models that can be used for evaluating Anti-Gastric ulcer potential of medicinal plants - Review Article. Austin Biology, 2016,1(2): 1- 9

10. Yadav P, Ganeshpurkar A and Rai G. In vitro $\mathrm{H}^{+} / \mathrm{K}^{+}$- ATPase inhibitory potential of methanolic extract of Cissus quadrangularis Linn. Pharmacognosy Research, 2012, 4(2): 123-126. 